\title{
A Comparative Study of Water Quality and Trophic State Contribution on Natural and Artificial Lakes Global Warming Potential
}

\section{Georgios Samiotis}

University of Western Macedonia

\section{Charoula Mavromatidou}

University of Western Macedonia

\section{Maria Ziagova}

University of Western Macedonia

\section{Eleni Trikilidou}

University of Western Macedonia

Elisavet Amanatidou ( $\nabla$ eamanatidou@uowm.gr)

University of Western Macedonia

\section{Research Article}

Keywords: Global warming potential, GHGs emissions, waterbodies, water quality, water quality index, trophic state index

Posted Date: July 29th, 2021

DOl: https://doi.org/10.21203/rs.3.rs-751199/v1

License: (c) (i) This work is licensed under a Creative Commons Attribution 4.0 International License. Read Full License 
1 A comparative study of water quality and trophic state contribution on

2 natural and artificial lakes global warming potential

3 Georgios Samiotis ${ }^{1}$, Charoula Mavromatidou', Maria Ziagova1', Eleni

$4 \quad$ Trikilidou $^{1}$, Elisavet Amanatidou ${ }^{*}$

$5{ }^{1}$ Laboratory of Environmental Chemistry \& Water and Wastewater Treatment,

6 Department of Chemical Engineering, University of Western Macedonia,

7 Kozani, Greece

$8 \quad{ }^{*}$ Corresponding author, email: eamanatidou@uowm.gr

9 Abstract

10 Natural lakes and reservoirs are emitters of GHGs in the atmosphere

11 contributing to $31 \%$ of the annual $\mathrm{CO}_{2}$ emissions of those from fossil fuel

12 combustion. Measurements of GHGs emissions in reservoirs demonstrate

13 that hydropower may actually not be as "green" as once thought. It is

14 estimated that emissions from reservoirs may be equivalent to $7 \%$ of the

15 global warming potential (GWP) of other documented anthropogenic

16 emissions. Aim of this work is to assess the impact of water quality

17 deterioration and the subsequent increment of biological productivity of a

18 waterbody on GHGs emissions. Therefore, the trophic state, the carbonic

19 GHGs emissions and the GWP of one natural lake domestic wastewater

20 receiver and two different age hydroelectric reservoirs, located in North

21 West Greece, were studied. Gross emissions of $\mathrm{CO}_{2}$ and $\mathrm{CH}_{4}$ were in-situ

22 measured using a static floating chamber and specific emissions as well as

23 GWP were calculated. Furthermore, water quality and trophic state were

24 evaluated based on the application of $\mathrm{Y} \Delta \Omega \mathrm{P}$ (hydõr) Water Quality Index

25 and Florida Trophic State Index using physicochemical characteristics 
measurements. Data statistical interpretation revealed that $\mathrm{CH}_{4}$ has strong positive correlation with GWP, temperature, water quality and trophic state. There is a seasonal variation of GWP that follows the seasonal variation of $\mathrm{CH}_{4}$ emissions induced by water temperature. Specific $\mathrm{CH}_{4}$ emission rate presents the most reliable indicator for assessing the impact of a waterbody in terms of GWP, especially of a hypertrophic one. Water quality and trophic state indices can be used for a rough comparison of GWP between waterbodies with the same climatic conditions.

Keywords: Global warming potential, GHGs emissions; waterbodies, water quality, water quality index, trophic state index.

\section{Introduction}

Anthropogenic activities, such as fossil fuel combustion, livestock, deforestation and creation of artificial wetlands significantly increase the concentration of greenhouse gases (GHGs) in the atmosphere and enhance greenhouse effect ${ }^{1,2}$. Natural lakes, freshwater reservoirs and other surface waters are of particular interest, since lentic ecosystems emit $110-810 \mathrm{Tg}$ $\mathrm{CO}_{2}-\mathrm{C}$ and $69-112 \mathrm{Tg} \mathrm{CH}_{4}-\mathrm{C}$ annually, constituting a great subject of discuss in the heart of a worldwide debate ${ }^{2,3,4}$. Their contribution on annual $\mathrm{CO}_{2}$ emissions is estimated at approximately $31 \%$ of those from fossil fuel combustion ${ }^{5}$. Measurements of GHGs emissions in reservoirs demonstrate that hydropower may actually not be as "green" as once thought. It is estimated that emissions from reservoirs may be equivalent to $7 \%$ of the global warming potential (GWP) of other documented anthropogenic emissions ${ }^{6}$. 

waterbody's trophic state, which in turn is a function of nutrients availability, usually phosphorous and less often nitrogen, as well as other parameters such as seasonal variations, grazing of phytoplankton by zooplankton, mixing depth of water, etc. ${ }^{7-11}$. According to European Environment Agency 12 the trophic status of a waterbody is classified into 5 categories, Oligotrophic, Oligo/Mesotrophic, Mesotrophic, Meso/Eutrophic and Eutrophic. The term Hypereutrophic has been also used for characterizing highly eutrophic waterbodies including artificial lakes mainly the first years of their formation ${ }^{13,14}$.

In freshwater reservoirs, carbon dioxide and methane are formed due to organic matter imported from the catchment area or produced due to plants and soils decomposition ${ }^{14}$. More specifically, $\mathrm{CO}_{2}$ is produced mainly in oxic (aerobic) conditions and sometimes in anoxic conditions in the water column, impounded soils and sediments of the reservoir, whereas is consumed (carbon fixation) by aquatic primary producers in the euphotic zone of a reservoir ${ }^{15,16}$. GHGs emissions are highly influenced by organic carbon in soils and topography. Reservoirs that flood peatlands emit more greenhouse gases in the long term than reservoirs built in canyons where little area is flooded, with limited peat deposits ${ }^{6}$.

In general, carbon dioxide emissions increase from oligotrophic to eutrophic lakes. Methane is produced under anaerobic conditions, primarily in the sediments, a portion of which is oxidized to $\mathrm{CO}_{2}$ by methanotrophic bacteria in both water column and sediments ${ }^{17}$. The fraction of $\mathrm{CH}_{4}$, which 
74 is oxidized before being emitted to the atmosphere, varies across freshwater aquatic systems depending on oxygen levels and temperature ${ }^{18}$.

Since nutrient availability is directly related to organic matter decomposition, monitoring and assessing the trophic state (status) of an aquatic system is essential to evaluate the environmental impact of reservoirs. The trophic status of an aquatic system indicates its environmental health and is expressed by a basic classification scale showing rather its biological productivity than its water quality. Trophic status can be calculated using Trophic State Indices (TSI), combining quality parameters, usually water clarity, algal activity, phosphorus and nitrogen availability ${ }^{19}$.

On the other hand, water quality assessment of an aquatic system is a more complicated procedure due to the numerous physicochemical and biological parameters that may affect it ${ }^{20}$. The plethora of factors needed to yield a single result of the overall water quality, such as (i) the large number of data necessary for the qualitative evaluation, (ii) the special knowledge and expertise required, as well as the (iii) difficulties arising in combining qualitative parameters characterized by different significance and expressed in different units of measurement and concentration ranges, make the assessment process particularly difficult ${ }^{21}$. A widely applied methodology for conveying the different water quality parameters in one single expression is the calculation of a Water Quality Index (WQI). A WQI is a number, a scale, a word, a symbol or a color that expresses the water quality of an aquatic system at a specific area in a specific period ${ }^{22,23}$. 
According to literature review, there are limited data regarding the

correlation of a waterbody's water quality and trophic state with GHGs emissions and subsequently GWP. Aim of this work is to correlate water quality and trophic state indices as well as GHGs emissions with GWP in order to obtain indicators for easily assessing GWP of waterbodies. For this purpose, one natural lake and two hydroelectric reservoirs were studied. Physicochemical characteristics and gross emissions of $\mathrm{CO}_{2}$ and $\mathrm{CH}_{4}$ were measured. Water quality and trophic state indices, as well as specific emissions and GWP were calculated and statistically interpreted.

\section{Materials and methods}

The research methodology of this work includes the selection of sampling stations and the measurement of water physicochemical parameters, $\mathrm{CO}_{2}$ and $\mathrm{CH}_{4}$ emissions in the collected samples. Thereafter, calculation of specific emission rates and GWP was carried out, whereas water quality and trophic state indices were also calculated. The obtained data were statistically processed using SPSS software and interpreted accordingly.

\subsection{Study area}

A natural lake (Zazari Lake) and two hydroelectric reservoirs (llarion and Polyfytos Reservoirs) were selected for the comparative assessment of GHGs emissions, water quality and trophic state. All three waterbodies are located in the area of North-West Greece presenting the same climatic conditions. (Figure 1). 


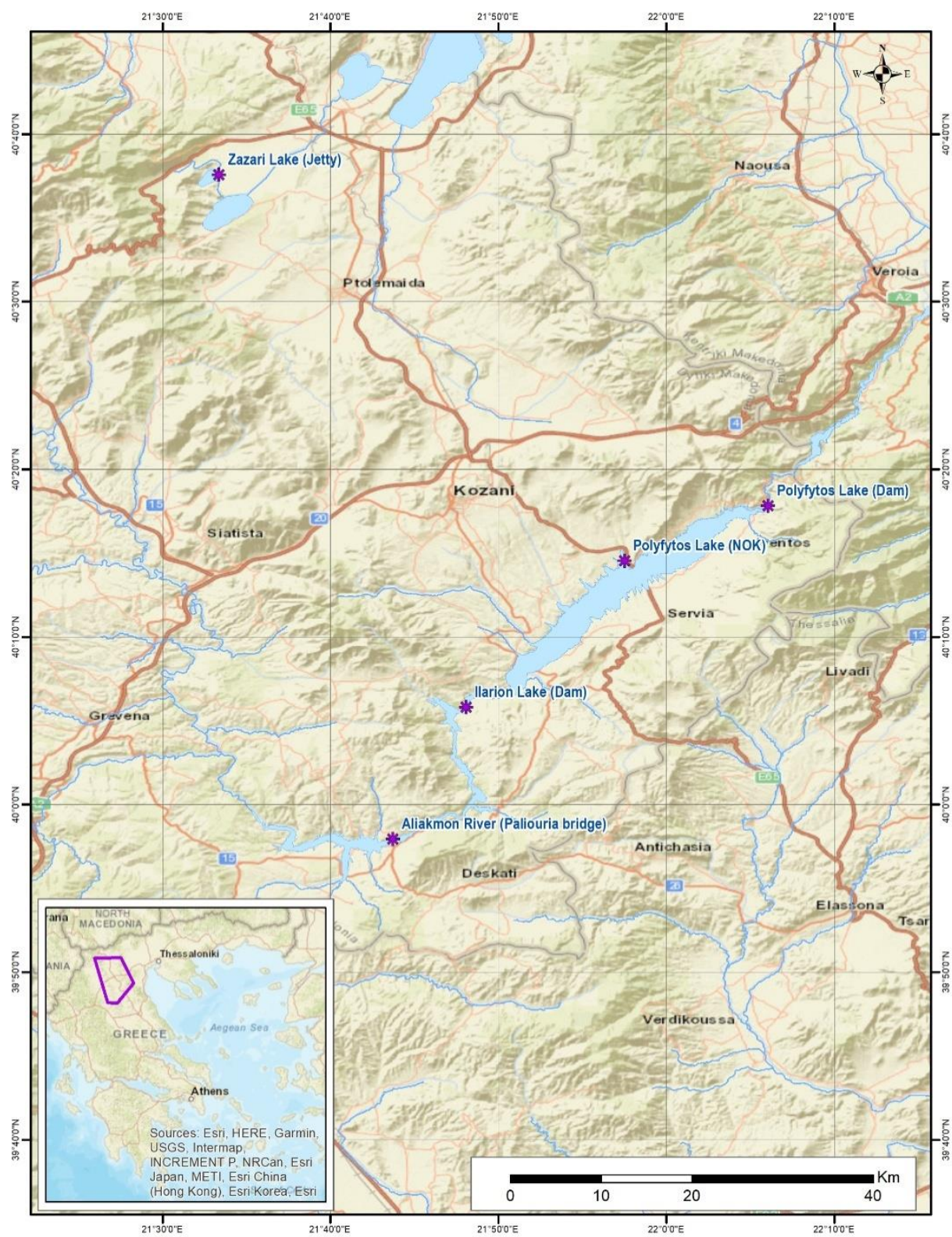

Figure 1. Study area map and sampling stations.

Zazari Lake is located in a relatively small flat area approximately 60 km North-West of llarion and Polyfytos Reservoirs, covering a surface of approximately $1.7 \mathrm{~km}^{2}$, with a maximum depth of approximately $6 \mathrm{~m}$ and is used mainly for irrigation and fishing. Five years ago, Zazari Lake was the final receiver of domestic wastewater from neighboring villages.

Ilarion and Polyfytos Reservoirs were created in 2012 and 1975 respectively, for the production of hydroelectric energy. Both reservoirs are 
129 fed with water from Aliakmon River, which is the longest river in Greece 130 (approximately $300 \mathrm{~km}$ ).

131 Ilarion Reservoir is a relatively young and small reservoir downstream

132 Aliakmon River, created in stiff rocky hills, forming a deeper canyon-like lake 133 (terrain slopes between $15^{\circ}$ to $45^{\circ}$ ). It covers a total surface of $22 \mathrm{~km}^{2}$ with a 134 maximum depth of $65 \mathrm{~m}$. Prior to its impoundment, $23.1 \%$ was river, $53.03 \%$ 135 was non-forest soil (grassland, rocks, and agricultural land), and $23.96 \%$ 136 was forest (plane and oak trees) ${ }^{24}$. Limited agricultural and livestock 137 activities and absence of other anthropogenic pressures characterize the 138 area.

Polyfytos Reservoir is significantly older and larger than llarion, having a surface of $73 \mathrm{~km}^{2}$ with a maximum measured depth of $22 \mathrm{~m}$. It was created in a rather flat agricultural area where Neraida village was located. Agricultural and livestock activities characterize the area around the 143 reservoir prior and post their impoundment $24,25$.

\subsection{Sampling and measurements}

145 Five sampling stations were selected (Figure 1), one in Zazari Lake, two in 146 Polyfytos Reservoir, one in llarion Reservoir and one in Aliakmon River 147 (sampling station Paliouria Bridge, western end of llarion Reservoir). The 148 maximum measured depth of the sampling stations varied from $4.5 \mathrm{~m}$ to $6 \mathrm{~m}$ 149 for Zazari Lake, 12 m to 14 m for Polyfytos NOK, 10 m to 12 m for Polyfytos 150 Dam and $5 \mathrm{~m}$ to $7 \mathrm{~m}$ for llarion Dam. The measured depth of Aliakmonas

151 River at the sampling station Paliouria Bridge ranged from $0.3 \mathrm{~m}$ to $1 \mathrm{~m}$. All 152 samplings were carried out from January 2018 to February 2019; samples 153 were collected from surface $(0.3 \mathrm{~m})$ and maximum depth in every sampling 

performed in North-West Greece.

156 Table 1. Sampling stations, sampling points, number of samples and type of 157 performed measurements.

\begin{tabular}{cccc}
\hline $\begin{array}{c}\text { Sampling } \\
\text { station }\end{array}$ & $\begin{array}{c}\text { Sampling } \\
\text { point }\end{array}$ & $\begin{array}{c}\text { Number of } \\
\text { samples }\end{array}$ & Type of Measurements \\
\hline $\begin{array}{c}\text { llarion } \\
\text { Reservoir }\end{array}$ & llarion Dam & 10 & $\begin{array}{r}\text { Physicochemical measurements in } \\
\text { water and in situ gross } \mathrm{CO}_{2} \text { and } \mathrm{CH}_{4} \\
\text { emission measurements }\end{array}$ \\
$\begin{array}{c}\text { Polyfytos } \\
\text { Reservoir }\end{array}$ & $\begin{array}{c}\text { Nautical Club } \\
\text { of Kozani } \\
\text { (Polyfytos } \\
\text { NOK) }\end{array}$ & 10 & $\begin{array}{r}\text { Physicochemical measurements in } \\
\text { water and in situ gross } \mathrm{CO}_{2} \text { and } \mathrm{CH}_{4} \\
\text { emission measurements }\end{array}$ \\
$\begin{array}{c}\text { Zazari } \\
\text { Lake }\end{array}$ & $\begin{array}{c}\text { Jetty (South- } \\
\text { West coast) }\end{array}$ & 8 & $\begin{array}{r}\text { Physicochemical measurements in } \\
\text { water and in situ gross } \mathrm{CO}_{2} \text { and } \mathrm{CH}_{4} \\
\text { emission measurements }\end{array}$ \\
$\begin{array}{c}\text { Paliouria } \\
\text { Bridge }\end{array}$ & $\begin{array}{c}\text { Aliakmon } \\
\text { River }\end{array}$ & 6 & $\begin{array}{r}\text { Physicochemical measurements in } \\
\text { water }\end{array}$ \\
\hline
\end{tabular}

A sub-surface water sampler was used for the collection of water samples. Water temperature and dissolved oxygen were measured in situ with a properly calibrated optical dissolved oxygen meter (Hach HQ30d).

All water samples were analyzed within a few hours from sampling by

162 the accredited, according to ISO 17025, Environmental Chemistry \& Water 163 and Wastewater Treatment Laboratory, of the University of Western 164 Macedonia, Greece. The parameters of $\mathrm{pH}$, Conductivity, Color, Turbidity, 165 Ammonium ions $\left(\mathrm{NH}_{4}{ }^{+}\right)$, Nitrite ions $\left(\mathrm{NO}_{2}^{-}\right)$, Total suspended solids (TSS), 166 Hexavalent Chromium $\left(\mathrm{Cr}^{+6}\right)$, Total organic Carbon (TOC), Total Kjeldahl 167 Nitrogen (TKN), Total Phosphorus (TP), Hardness, Alkalinity and 168 Chlorophyll-a were analyzed according to standard methods 26 . The 169 parameters of $\mathrm{Cl}^{-}, \mathrm{NO}_{3}{ }^{-}, \mathrm{SO}_{4}^{-2}, \mathrm{~K}^{+}, \mathrm{Na}^{+}, \mathrm{Ca}^{+2}$ and $\mathrm{Mg}^{+2}$ were analyzed by lon 
170 Chromatography (IC), according to ISO 10304-1 (2007) and ISO14911 171 (1998) 27, 28, using a Metrohm Chromatographer (model 881 Compact IC 172 pro), equipped with an electrical conductivity detector and two Metrosep 173 columns (models A SUPP 5250 and C 2 250/4).

For the collection of GHGs emissions, specifically $\mathrm{CO}_{2}$ and $\mathrm{CH}_{4}$, a static floating chamber was used. The static floating chamber was a closeended, stainless steel, rectangular box, $0.50 \mathrm{~m}$ in height, $0.50 \mathrm{~m}$ in width, and $1 \mathrm{~m}$ in length, equipped with a floating buoy, constructed using a $0.20 \mathrm{~m}$ $\varnothing$ rubber tube, filled with polyurethane foam. Gas samples were collected after $0 \mathrm{~min}, 50 \mathrm{~min}, 90 \mathrm{~min}, 130 \mathrm{~min}$, and $180 \mathrm{~min}$ in low permeability, multilayered foil bags (Supel ${ }^{\mathrm{TM}}$ - Inert Multi-Layer Foil Bag), suitable for gas sample collection. Gas chromatography for the determination of $\mathrm{CO}_{2}$ and $\mathrm{CH}_{4}$ concentrations was performed using a SHIMADZU 14B, equipped with thermal conductivity (TCD) and flame ionization (FID) detectors as well as with a Molecular Sieve $13 \times(10 \mathrm{ft} . \times 1 / 8$ in.) and a Porapack QS (10 ft. × 1/8 in.) column for gas separation. Both columns were heated at $80^{\circ} \mathrm{C}$.

The specific GHGs emission rate was calculated according to Equation (1), using $\mathrm{CO}_{2}$ and $\mathrm{CH}_{4}$ concentration measurements with the static floating chamber previously described. where: $C$ is the specific gas emission rate $\left(\mathrm{mg} \mathrm{m}^{-2} \mathrm{~h}^{-1}\right) ; \rho$ is the gas density 191 in standard conditions $\left(\mathrm{kg} \mathrm{m}^{-3}\right) ; d C / d t$ is the linear regression of gas concentration in static floating chamber; $H$ is the height $(m)$ from the

193 chamber top to the water surface; $T$ is the air temperature $\left({ }^{\circ} \mathrm{C}\right)$ inside the 194 chamber ${ }^{29}$. 


\subsection{Characterization of water quality}

Water quality classification was carried out using a new WQI developed at the department of Chemical Engineering - University of Western Macedonia, named $Y \triangle \Omega P W Q I$ (hydõr $=$ water in ancient Greek). $Y \triangle \Omega P W Q I$ is considered to be a sensitive and flexible tool for assessing water quality, as it (a) prioritizes monitoring parameters, (b) redefines weight coefficients based on experts' opinion, (c) inserts in its calculation the ideal values, (d) takes into consideration both legislation and experts' opinion and (e) is sensitive to marginal conditions, in contrast to other water quality indices ${ }^{30}$, 31. $Y \triangle \Omega P W Q /$ is calculated by Equation 2 .

$\Upsilon \Delta \Omega P W Q I=\frac{\sum_{i=1}^{n}\left[\operatorname{Average}\left(q_{i} \times R W i\right)\right]+\sum_{i=1}^{n}\left[R i, e \times \operatorname{Average}\left(q_{i, e} \times R W i\right)\right]}{\sum_{i=1}^{n} R W i}$

where: $q i$ is the Sub-index of sample for $i$ parameter; qi,e is the Sub-index of sample for $i$ parameter exceeding permitted value; $R W i$ is the relative weight of $i$ parameter (obtained from Mavromatidou et al., 2020) ${ }^{30}$; Ri,e is the ratio of samples exceeding permitted value of parameter $i$ to total number of samples of parameter $i ; n$ is the number of control parameters

The sub-index is calculated according to Equation (3), which is taking under account the measured physicochemical and microbiological water quality parameter values, the standard values deriving from legislation limits and the desired or ideal values.

$q_{i}=\frac{100 \times\left|C_{i}-V_{i 0}\right|}{\left|S_{i}-V_{i 0}\right|}$

where: $\mathrm{Ci}$ is the measured value of the $i$ water quality parameter; $\mathrm{Si}$ is the permitted $i$ water quality parameter value obtained from legislation; Vio is the ideal value of $i$ water quality parameter. 
The parameters included in the calculation of $Y \triangle \Omega P W Q I$ were:

220 Hexavalent Chromium, E-coli, Lead, Arsenic, Cadmium, Fecal Coliforms,

221 Total Pesticides, Mercury, Ammonium, COD, Nitrite lons, Nitrate lons, Total

222 Phosphorus (TP) and Chlorides (Total Pesticides, Lead, Arsenic, Cadmium

223 and Mercury measurement data were provided from the Greek Ministry of

224 Rural Development and Food, $\left.(2020 \text { a,b })^{32,}{ }^{33}\right)$. The permitted values of

225 control parameters were obtained from the limit values of European

226 directives and national legislation regarding quality of internal surface,

227 ground and drinking waters. For ideal values, the Lower Detection Limit

228 (LDL) of each parameter was used. The classification of water quality

229 according to $Y \triangle \Omega P W Q I$ is presented in Table 2.

230 Table 2. Characterization of lakes according to $Y \triangle \Omega P W Q I$ results 231 (Mavromatidou et al., 2020).

\begin{tabular}{cc}
$Y \Delta \Omega P W Q I$ scale & $\begin{array}{c}\text { Water Quality Characterization } \\
\text { (Based on physicochemical and } \\
\text { microbiological characteristics) }\end{array}$ \\
\hline $0 \leq Y \triangle \Omega P W Q I \leq 10$ & Excellent \\
$10<Y \triangle \Omega P W Q I \leq 25$ & Good \\
$25<Y \triangle \Omega P W Q I \leq 50$ & Fair \\
$50<Y \triangle \Omega P W Q I \leq 100$ & Marginal \\
$Y \triangle \Omega P W Q I>100$ & Poor \\
\hline
\end{tabular}

232

233

\subsection{Characterization of trophic state}

Trophic state characterization of every waterbody was based on the calculation of a TSI, more specifically, the Florida TSI (FTSI) ${ }^{13,34}$. FTSI is based on the same rationale as that of Carlson $(1977)^{35}$, who introduced the concept of classifying the trophic state of a waterbody using measurement data regarding Turbidity (Secchi depth), Chlorophyll concentration and TP concentration. FTSI excluded turbidity, while included the parameter of Total Nitrogen (TN) as a third indicator. Turbidity was excluded because it was 
causing problems in dark-water lakes and estuaries, where dark-waters rather than algae diminish transparency ${ }^{34}$.

In order to apply FTSI, each waterbody's limiting nutrient, must be determined, which is usually phosphorous and less often nitrogen ${ }^{13}$. The limiting nutrient is determined based on the ratio of TN concentration to TP concentration. For TN/TP $<10$ the liming nutrient is Nitrogen, for TN/TP $>$ 30 is Phosphorus, while for $10 \leq \mathrm{TN} / \mathrm{TP} \leq 30$ there is no limiting nutrient (nutrient balanced waterbody) ${ }^{36}$. Regarding FTSI calculation in Polyfytos reservoir, mean values of TP, TN and Chlorophyll $\alpha$ from the two sampling stations were used.

For the determination of the overall trophic state index using FTSI, a separate component (sub-index) for each parameter was calculated, depending on the limiting nutrient, using the appropriate formula (Equation 4 to Equation 8), followed by the appropriate combination of the sub-indexes, as indicated in Equation A to Equation C. The equation for the calculation of Chlorophyll a sub-index $\left(C H L A_{T S I}\right)$ is the same (Equation 4) regardless the limiting nutrient. On the contrary, the nutrient status of a lake dictates the empirical formula that is used for Nitrogen and for Phosphorus sub-indices calculation. For nutrient-balanced lakes (10 $\leq$ TN/TP $\leq 30)$ Equation 5 and Equation 6 are used; for phosphorus-limited lakes (TN/TP >30), Equation 7 is used, whereas for nitrogen-limited lakes, Equation 8 is used FTSI sub-index formulas:

$$
\begin{aligned}
& C H L A_{T S I}=16.8+[14.4 \times \ln (C H L A)] \\
& T P_{T S I}=[18.6 \times \ln (T P \times 1000)]-18.4 \\
& T N_{T S I}=56+[19.8 \times \ln (T N)]
\end{aligned}
$$




$$
T P 2_{T S}=10 \times[2.36 \times \ln (T P \times 1000)-2.38]
$$

$$
T N 2_{T S I}=10 \times[5.96+2.15 \times \ln (T N+0.0001)]
$$

FTSI overall index formulas:

$$
T S I=\frac{C H L A_{T S I}+\frac{T N_{T S I}+T P_{T S I}}{2}}{2}
$$

$$
T S I=\frac{C H L A_{T S I}+T P 2_{T S I}}{2}
$$

$$
T S I=\frac{C H L A_{T S I}+T N 2 T S I}{2}
$$

Based on the results of overall FTSI, the waterbodies are classified 272 according to their trophic state as "Oligotrophic", "Mid-Eutrophic",

273 "Eutrophic" and "Hypereutrophic" and corresponds to "Good", "Fair" and 274 "Poor" water quality respectively (Table 3). A "Good" lake water quality is 275 one that meets all lake-use criteria (swimmable, fishable and supports 276 healthy habitat); a "Fair" lake water quality can be considered highly 277 productive and a reasonable lake for fishing and most water sports, while a 278 "Poor" lake water quality means that probably the lake use criteria are not 279 meet ${ }^{13}$.

280 Table 3. Classification and characterization of lakes according to FTS/ results 281 13.

\begin{tabular}{ccc}
\hline FTSI scale & $\begin{array}{c}\text { Trophic State } \\
\text { Classification }\end{array}$ & $\begin{array}{c}\text { Water Quality } \\
\text { Characterization } \\
\text { (Based on trophic status) }\end{array}$ \\
\hline 0 to 59 & $\begin{array}{c}\text { Oligotrophic through } \\
\text { Mid-Eutrophic } \\
\text { Mid-Eutrophic through } \\
\text { Eutrophic } \\
\text { Hypereutrophic }\end{array}$ & Good \\
\hline
\end{tabular}


283 The Global Warming Potential was developed to allow comparisons of the 284 global warming impacts of different gases. Each greenhouse gas has different GWP. $\mathrm{CO}_{2}$, by definition, has a GWP of 1 regardless of the time period used, because it is the gas being used as the reference. $\mathrm{CH}_{4}$ is considered to have 20 times higher GWP than that of $\mathrm{CO}_{2}$ on over a 100 to 150 -year period ${ }^{37}$.

The calculation of GWP in relation to season and for a monthly step, was carried out using the average values of $\mathrm{CO}_{2}$ and $\mathrm{CH}_{4}$ specific emissions for the year 2018, as well as from 2014 to 2016 as described in our previous work ${ }^{24}$.

\subsection{Data evaluation and statistical analysis}

The samples' analysis results were statistically processed and interpreted using the SPSS statistical software. For testing the significant differences among the values of the measured parameters corresponding to depth and surface samples, the independent variables $t$-test was used. A significance level of 0.05 or $95 \%$ confidence interval was set. For the evaluation of correlation between measured and calculated parameters, the Spearman's rank correlation hypothesis test was applied setting a significance level of 0.05 .

\section{Results and Discussion}

\subsection{Assessment of significant differences between sampling stations} Independent variable $t$-test between the measured physicochemical parameters of surface and maximum depth samples at all sampling stations (comparative data from the first three samplings) showed that:

- Polyfytos and Ilarion Reservoir presented no significant statistical difference (Sig. > 0.05) for none of the twenty-two examined parameters. 
This may be attributed to the low hydraulic residence time due to water

309 discharges as well as the continuous mixing of the waterbody's layers

310 from dam 25,38 .

311 - In Paliouria Bridge, due to its low depth, no stratification occurred and

312 hence no significant differences in water quality were observed; none of

313 the twenty-two examined parameters presented significant statistical

314 differences between surface and depth samples. Paliouria Bridge

315 sampling station in Aliakmon River is a river to lake transition area that

316 inundated last and has significant changes in depth due to dam operation

317 and Aliakmon River flow ${ }^{25}$.

318 - In Zazari Lake, only chlorophyll a, exhibited significant statistical difference

319 between surface and depth samples (t-test, Sig.=0.001). This may be

320 attributed to water stratification of the lake, due to phototrophic organisms'

321 growth. The relatively high turbidity and color in Zazari Lake as well as its

322 relatively low mixing of water, indicative of natural lakes, may cause higher

323 growth rate of phototrophic organisms at the surface of the lake in relation

324 to those present in the deeper levels, where the transfer of

325 photosynthetically active radiation (PAR) is significantly obstructed 5,39 .

326 Leach et al. (2018) found that the variation in chlorophyll $\alpha$ concentrations

327 with depth in lake water is influenced more by light attenuation than thermal

328 stratification ${ }^{40}$. Reservoirs differ from natural lakes in terms of hydraulic

329 residence time (HRT), loads of total suspended solids, and productivity ${ }^{38}$,

$330 \quad 41$. Moreover, hydrological variability induced by anthropogenic

331 manipulation of inflow/outflow can affect the variation with depth in

332 constituents in lakes and reservoirs. 
334 depth regarding the examined parameters in all sampling stations, as well

335 as due to the fact that the differences in chlorophyll a measurements 336 between surface and depth in Zazari Lake did not affect either the 337 characterization in terms of water quality and trophic state or the results of 338 statistical correlations, all subsequent water samples were collected only 339 from the maximum depth.

340 Independent variable $t$-test between the measurements of 341 physicochemical parameters at the two sampling stations of Polyfytos 342 Reservoir (Figure 1, Polyfytos Dam and Polyfytos NOK) showed that there 343 are non-significant differences $(\mathrm{Sig}>0.05)$ regarding 20 of the 22 examined 344 parameters. According to the results of the statistical analysis only nitrates 345 and turbidity presented significant statistical differences (Sig. $=0.002$ and 3460.029 respectively). Nevertheless, these differences in nitrates and turbidity 347 measurements between the two sampling stations of Polyfytos Reservoir did 348 not affect either the characterization in terms of water quality and trophic 349 state or the results of statistical correlations. Thus, both Polyfytos sampling 350 stations were accounted as one for the calculation of $Y \triangle \Omega P W Q I$ and FTSI, 351 as well as for the statistical analysis between all sampling stations.

352 In Table 4, the average values of each physicochemical parameter in 353 every sampling period along with their standard deviation are presented.

354 Table 4. Average values and standard deviation of physicochemical 355 parameters at maximum depth of each sampling station

\begin{tabular}{|c|c|c|c|c|c|c|c|c|}
\hline Parameter & $\begin{array}{c}\text { Zazari } \\
\text { Lake }\end{array}$ & $\begin{array}{l}\text { Std. } \\
\text { Dev. }\end{array}$ & $\begin{array}{c}\text { llarion } \\
\text { Reservoir }\end{array}$ & $\begin{array}{l}\text { Std. } \\
\text { Dev. }\end{array}$ & $\begin{array}{l}\text { Polyfytos } \\
\text { Reservoir }\end{array}$ & $\begin{array}{l}\text { Std. } \\
\text { Dev. }\end{array}$ & $\begin{array}{c}\text { Paliouria } \\
\text { Bridge }\end{array}$ & $\begin{array}{l}\text { Std. } \\
\text { Dev. }\end{array}$ \\
\hline $\mathrm{pH}$ & 8.17 & 0.61 & 8.13 & 0.31 & 8.17 & 0.34 & 8.22 & 0.18 \\
\hline $\begin{array}{l}\text { D.O., \% } \\
\text { saturation }\end{array}$ & 118 & 6.20 & 82 & $\begin{array}{c}10.4 \\
1\end{array}$ & 102 & $\begin{array}{c}20.6 \\
7\end{array}$ & 100 & 15.34 \\
\hline
\end{tabular}




\begin{tabular}{|c|c|c|c|c|c|c|c|c|}
\hline $\begin{array}{l}\text { Conductivity, } \\
\mu S / \mathrm{cm}\end{array}$ & 175.66 & 11.37 & 388.25 & $\begin{array}{c}20.8 \\
9\end{array}$ & 405.17 & $\begin{array}{c}29.8 \\
3\end{array}$ & 402.05 & 56.57 \\
\hline Color, Hazen & 8.62 & 5.08 & 10.34 & 4.46 & 6.99 & 3.72 & 24.05 & 9.12 \\
\hline $\begin{array}{l}\text { Turbidity, } \\
\text { NTU }\end{array}$ & 5.51 & 8.70 & 1.77 & 1.04 & 1.18 & 1.42 & 75.30 & 57.70 \\
\hline TSS, mg/l & 11.60 & 1.27 & 2.63 & 1.80 & 3.1 & 1.87 & 22.20 & 17.07 \\
\hline $\mathrm{NO}_{3}^{-}, \mathrm{mg} / \mathrm{l}$ & 0.53 & 0.39 & 1.18 & 0.99 & 1.11 & 0.86 & 1.90 & 0.78 \\
\hline $\mathrm{NO}_{2}^{-}, \mu \mathrm{g} / \mathrm{l}$ & 7.32 & 5.73 & 23.78 & $\begin{array}{c}14.3 \\
6\end{array}$ & 12.48 & $\begin{array}{c}11.3 \\
1\end{array}$ & 52.75 & 21.05 \\
\hline $\mathrm{NH}_{4}{ }^{+}, \mathrm{mg} / \mathrm{l}$ & 0.11 & 0.21 & 0.11 & 0.22 & 0.02 & 0.03 & 0.03 & 0.03 \\
\hline $\begin{array}{l}\text { Alkalinity, } \\
\mathrm{mg} / \mathrm{l}\end{array}$ & 92.96 & 80.44 & 179.16 & $\begin{array}{c}15.6 \\
6\end{array}$ & 205.60 & $\begin{array}{c}20.5 \\
3\end{array}$ & 204.20 & 23.05 \\
\hline $\begin{array}{l}\text { Hardness, } \\
\mathrm{mg} / \mathrm{l}\end{array}$ & 63.21 & 15.06 & 213.75 & $\begin{array}{c}21.0 \\
5\end{array}$ & 216.95 & $\begin{array}{c}65.5 \\
0\end{array}$ & 148.80 & 46.67 \\
\hline $\mathrm{Cl}^{-}, \mathrm{mg} / \mathrm{l}$ & 4.09 & 1.31 & 5.47 & 0.88 & 6.56 & 2.70 & 6.40 & 1.58 \\
\hline TOC, mg/l & 4.49 & 6.34 & 5.19 & 3.90 & 3.73 & 3.28 & 5.75 & 1.34 \\
\hline $\mathrm{TKN}, \mathrm{mgN} / \mathrm{l}$ & 4.65 & 2.62 & 1.40 & 0.61 & 1.78 & 0.90 & 1.89 & 0.30 \\
\hline $\mathrm{Ca}^{+2}, \mathrm{mg} / \mathrm{l}$ & 15.60 & 0.71 & 34.80 & 3.41 & 38.61 & 5.36 & 22.75 & 12.87 \\
\hline $\begin{array}{l}\text { Chlorophyll } a \text {, } \\
\mu \mathrm{g} / \mathrm{l}\end{array}$ & 18.89 & 1.70 & 1.40 & 0.76 & 2.55 & 1.98 & 0.52 & 0.63 \\
\hline $\mathrm{Cr}^{+6}, \mu \mathrm{g} / \mathrm{l}$ & 6.15 & 1.49 & 2.43 & 1.01 & 0.76 & 1.40 & 4.70 & 7.12 \\
\hline $\mathrm{TP}, \mathrm{mgP} / \mathrm{l}$ & 1.29 & 1.41 & 0.007 & $\begin{array}{c}0.00 \\
4\end{array}$ & 0.45 & 0.49 & 0.083 & 0.055 \\
\hline $\mathrm{Na}^{+}, \mathrm{mg} / \mathrm{l}$ & 7.98 & 0.60 & 5.46 & 2.08 & 5.88 & 1.12 & 5.81 & 6.14 \\
\hline $\mathrm{K}^{+}, \mathrm{mg} / \mathrm{l}$ & 3.46 & 0.25 & 1.57 & 0.22 & 1.65 & 0.06 & 1.40 & 1.28 \\
\hline $\mathrm{Mg}^{+2}, \mathrm{mg} / \mathrm{l}$ & 4.45 & 0.30 & 25.80 & 0.35 & 22.74 & 1.07 & 22.20 & 1.69 \\
\hline $\mathrm{SO}_{4}^{-2}, \mathrm{mg} / \mathrm{l}$ & 8.50 & 1.20 & 22.34 & 5.42 & 19.16 & 4.15 & 18.3 & 3.34 \\
\hline
\end{tabular}

357 are indicative of changes of water quality between samplings. Nevertheless,

358 the high differences in measured values did not hinder the results regarding

359 the characterization of the waterbodies in terms of water quality and trophic

360 state, since the application of $Y \triangle \Omega P W Q I$ and $F T S /$ using average parameter

361 values plus their standard deviation presented similar results and identified

362 the differences between the three waterbodies.

363 As it can be seen in Table 4, all sampling stations of Aliakmon River

364 basin except Zazari Lake present similar water quality characteristics.

365 Statistical analysis of all physicochemical parameters between all sampling

366 stations showed significant differences $(t$-test, $p<0.05)$ only in Zazari Lake. 
The similar water quality of sampling stations at Aliakmon River basin is

368 attributed to their common feed. More specifically, water of Paliouria Bridge

369 supplies Ilarion Reservoir, which thereafter replenishes Polyfytos Dam.

370 Higher values of Color, Turbidity and TSS were only reported in Paliouria

371 Bridge sampling station, due to the shallow depth $(0.3-1 \mathrm{~m})$ and the flow of

372 Aliakmon River.

373 3.2. Assessment of water quality, trophic state and carbonic emissions

374 The waterbodies quality and trophic state classification according to $375 Y \triangle \Omega P W Q I$ and FTSI respectively, as well as $\mathrm{CO}_{2}$ and $\mathrm{CH}_{4}$ specific 376 emissions are presented in Table 5. Y $\triangle \Omega P W Q$ and FTS/ were calculated as 377 described in Materials and Methods, sections 2.3. and 2.4., based on the 378 average measured values (Table 4). The range of $\mathrm{CO}_{2}$ and $\mathrm{CH}_{4}$ specific 379 emissions as well as the average specific emissions were calculated as 380 described in Materials and Methods, section 2.2., based on measured 381 emission rates using a static floating chamber.

382 Table 5. Measurement data; classification / characterization of waterbodies 383 based on FTSI and $Y \triangle \Omega P W Q I$ calculation.

\begin{tabular}{lccc}
\hline Parameter & llarionas Reservoir & Polyfytos Reservoir & Zazari Lake \\
\hline TN/TP ratio & 137 & 4.07 & 3.71 \\
Nutrient status & $\begin{array}{c}\text { Phosphorus-Limited } \\
\text { Lake }\end{array}$ & Nitrogen-Limited & $\begin{array}{c}\text { Nitrogen- } \\
\text { Limited Lake }\end{array}$ \\
FTSI & 20.1 & Lake & 76.3 \\
FTSI classification & Oligotrophic through & Oligotrophic through & Hypereutroph \\
& Mid-Eutrophic & Mid-Eutrophic & ic \\
FTSI characterization & GOOD & GOOD & POOR \\
\hline
\end{tabular}


$Y \triangle \Omega P W Q I$

21.4

45.2

112.5

$Y \triangle \Omega P W Q I$

characterization

GOOD

FAIR

POOR

Specific $\mathrm{CO}_{2}$ emission

rate $\left(\mathrm{mg} \mathrm{m}^{-2} \mathrm{~d}^{-1}\right)$

65.8 to 1144.8

98.0 to 761.4

-731.9 to

2000.7

Average specific $\mathrm{CO}_{2}$

emission rate $\left(\mathrm{mg} \mathrm{m}^{-2} \mathrm{~d}^{-1}\right)$

389.8

391.9

309.7

Specific $\mathrm{CH}_{4}$ emission

rate $\left(\mathrm{mg} \mathrm{m}^{-2} \mathrm{~d}^{-1}\right)$

0 to 19

0 to 43.2

0 to 2236.9

Average specific $\mathrm{CH}_{4}$

emission rate $\left(\mathrm{mg} \mathrm{m}^{-2} \mathrm{~d}^{-1}\right)$

4.6

13.3

673.4

The water quality of the older and considered stabilized Polyfytos

385 Reservoir and the younger llarion Reservoir is characterized as "Fair" and

386 "Good" respectively, according to $Y \triangle \Omega P W Q I$ (Table 5). On the contrary, in 387 our previous work (2012-2015 monitoring period) and during llarion

388 Reservoir maturation period, Polyfytos Reservoir was characterized by

389 better water quality than Ilarion ${ }^{25}$. Taking into consideration that Ilarion

390 Reservoir has formed in a rocky area (canyon), this improvement in water

quality suggests that it has entered in stabilization period approximately six years after its creation, earlier than the ten years period suggested by other

393 studies 6, 42. This highlights the importance of site selection in the

394 construction of water reservoirs for hydroelectric energy production, since

395 both specific morphology and absence of anthropogenic activities can lead

396 to a good water quality only a few years after inundation of an area.

According to the results of FTSI, Polyfytos and Ilarion Reservoirs are

398 classified as oligotrophic through mid-eutrophic waterbodies, with Ilarion

399 Reservoir presenting better trophic state than Polyfytos (Table 5). This is in 
400

401

402

403

404

405

406

407

408

409

410

411

412

413

414

415

416

417

418

accordance with the previous results of $Y \triangle \Omega P W Q I$, where young llarion Reservoir exhibited better water quality indicative of its stabilization.

The respective average specific $\mathrm{CO}_{2}$ and $\mathrm{CH}_{4}$ emissions in Polyfytos

Reservoir are $391.9 \mathrm{mg} \mathrm{m}^{-2} \mathrm{~d}^{-1}$ and $13.3 \mathrm{mg} \mathrm{m}^{-2} \mathrm{~d}^{-1}$ and in llarion Reservoir $389.8 \mathrm{mg} \mathrm{m}^{-2} \mathrm{~d}^{-1}$ and $4.6 \mathrm{mg} \mathrm{m}^{-2} \mathrm{~d}^{-1}$. The emissions of $\mathrm{CO}_{2}$ and $\mathrm{CH}_{4}$ were relatively low in both Polyfytos and Ilarion Reservoirs, regardless their age difference, presenting non-significant statistical ( $t$-test) difference in terms of specific $\mathrm{CO}_{2}$ emission rate $(\mathrm{Sig} .=0.499)$ and specific $\mathrm{CH}_{4}$ emission rate $($ Sig. $=0.985)$. Nevertheless, Polyfytos Reservoir, exhibited three times higher productivity in terms of specific $\mathrm{CH}_{4}$ emission rate when compared to Ilarion emissions. This is attributed to the relatively flat area with fertile soils that was impounded and to agricultural and livestock activities that increase inflow of organic matter in the reservoir contributing to higher GHGs emissions ${ }^{43}$. GHGs specific emissions from these two in-line reservoirs were also calculated in our previous work ${ }^{24}$ for collected data of the years 2014-2016. During this period, it was found that the average specific $\mathrm{CO}_{2}$ emission rate was 563.3 and $496.3 \mathrm{mg} \mathrm{m}^{-2} \mathrm{~d}^{-1}$, whereas the average specific $\mathrm{CH}_{4}$ emission rate was 38.5 and $28.9 \mathrm{mg} \mathrm{m}^{-2} \mathrm{~d}^{-1}$ in the case of Polyfytos and Ilarion respectively. Two years after the 2014-2016 monitoring period, the lower GHGs emissions measured in Ilarion Reservoir (see Table 5), as well as the limited biomass impoundment (canyon-like rocky area) indicate that this reservoir has reached its stabilization period, which is in accordance with the results obtained from the comparison of water quality indices between the two reservoirs. The fact that Ilarion Reservoir has entered its stabilization period only six years after its formation renders the selection of 
the reservoir location a crucial parameter on the assessment of how green is an investment on hydroelectric energy.

In Zazari Lake the respective average specific $\mathrm{CO}_{2}$ and $\mathrm{CH}_{4}$ emissions are $309.7 \mathrm{mg} \mathrm{m}^{-2} \mathrm{~d}^{-1}$ and $673.4 \mathrm{mg} \mathrm{m}^{-2} \mathrm{~d}^{-1}$. Zazari natural lake (a) exhibits "Poor" water quality according to $Y \triangle \Omega P W Q I$, reflecting the degradation of organics due to domestic wastewater disposal (five years ago) from nearby villages (b) is characterized as hypereutrophic lake and (c) exhibits significantly higher GHGs emissions, especially regarding $\mathrm{CH}_{4}$ emissions comparing with llarionas and Polyphytos Reservoirs (Sig. $=0.043$ and Sig. $=0.033$ respectively). It is worth mentioning that, despite the relatively low depth at Zazari Lake sampling station $(4.5 \mathrm{~m}$ to $6 \mathrm{~m})$ methanogenesis occurred at significantly high rates (mean value $673.4 \mathrm{mg}$ $\left.\mathrm{m}^{-2} \mathrm{~d}^{-1}\right)$. This is attributed to the hypertrophic state of Zazari Lake, which results in the creation of anoxic conditions, enhancing anaerobic biological processes ${ }^{44}$. Davidson et al. (2015) also found that nutrients concentration in a shallow eutrophic lake, such as Zazari Lake, have a profound effect in GHGs emission ${ }^{45}$. Domestic pollution of Zazari Lake ceased five years ago. Considering the significantly higher $\mathrm{CH}_{4}$ emissions of Zazari Lake, as well as the deteriorated water quality and trophic state compared to that of Polyfytos and Ilarion Reservoirs, it is concluded that Zazari Lake can be characterized as a young artificial reservoir that has not yet been stabilized. According to the results of this study, llarion Reservoir has entered its stabilization period (lower emissions) six years after its formation, while Zazari Lake five years after domestic pollution ceased still emits significant 
quantities of GHGs. Consequently, both morphology and anthropogenic activities affect the stabilization time of a waterbody.

According to Spearman statistical test, temperature presents strong positive correlation with $\mathrm{CH}_{4}$ specific emissions (Corr. Coef. $=0.727$, Sig. $<$ 0.001) and GWP (Corr. Coef. $=0.823$, Sig. $<0.001$ ), indicative of the positive effect of temperature on methanogenesis.

On the other hand, $\mathrm{CO}_{2}$ specific emissions present significant negative correlation with turbidity (Corr. Coef. $=0.728$, Sig. $<0.001$ ), a parameter that is indicative of the presence of microorganisms in a waterbody. This negative correlation as well as the absence of a similar strong negative correlation between $\mathrm{CO}_{2}$ emissions and chlorophyll $\alpha$ shows that the presence of autotrophic microorganisms play a major role in carbon fixation by assimilating $\mathrm{CO}_{2}{ }^{46}$. The growth of chemolithotrophic bacteria that can fixate $\mathrm{CO}_{2}$ or/and oxidise $\mathrm{CH}_{4}$ could be triggered by the increased availability of specific nitrogenous nutrients, as indicated by the strong positive correlation (Sig. < 0.03) between turbidity and ammonium, nitrites and nitrates. Furthermore, the strong negative correlation of sulphates with the emission rates of $\mathrm{CO}_{2}$ (Corr. Coef. $=-0.964$, Sig. $\left.=0.001\right)$ and $\mathrm{CH}_{4}$ (Corr. Coef. $=-$ 0.794 , Sig. $=0.008$ ), as well as the positive correlation of sulphates with turbidity (Corr. Coef. $=0.420$, Sig. $=0.037$ ) indicate the presence of sulphate reducing chemolithotrophs and their effect on $\mathrm{CO}_{2}$ fixation and $\mathrm{CH}_{4}$ oxidation 46.

\subsection{Variability of GHGs emissions and statistical interpretation}

The strong relation between carbonic GHGs emissions and seasonal changes of temperature is also evident in Figure 2 regarding the study area at North- 
474 West Greece. The average water temperature of the studied waterbodies was $475 \quad 7.2^{\circ} \mathrm{C}$ to $14.8^{\circ} \mathrm{C}$ during the colder period (November to March), while during 476 the warmer period (April to October) ranged from $18.8^{\circ} \mathrm{C}$ to $25.1^{\circ} \mathrm{C}$. These 477 differences in temperature result in a seasonal pattern regarding GWP of the 478 waterbodies. As it can be seen from Figure 2, GWP increases in warmer 479 period, when both $\mathrm{CO}_{2}$ and $\mathrm{CH}_{4}$ emissions are recorded, whereas it 480 decreases in colder period due to methanogenesis inhibition and the sole 481 production of $\mathrm{CO}_{2}$. This seasonal pattern is also observed in $\mathrm{CH}_{4}$ emissions, 482 but is not observed in $\mathrm{CO}_{2}$ emissions which are greatly affected by the 483 presence of algae (carbon fixation) and a plethora of physicochemical 484 parameters, such as salinity, $\mathrm{pH}$, alkalinity and water temperature ${ }^{47}$. 485 Interestingly, GWP is steeply increased, following $\mathrm{CH}_{4}$ specific emissions in 486 warmer period, further confirming the results of statistical process.

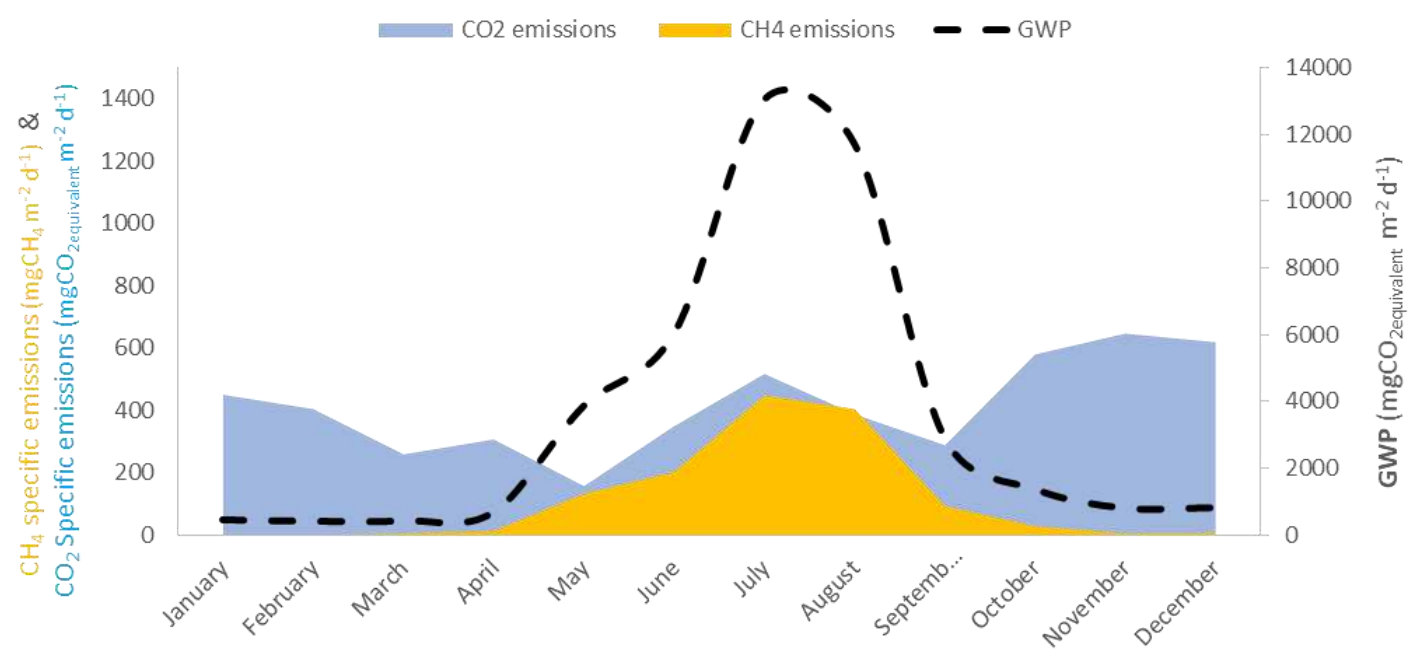

487

488 Figure 2. Monthly average specific emission rates* and GWP $^{\star}$ of llarion, 489 Polyfytos and Zazari sampling stations. *calculated from current (2018) 490 measurement data (present study) and older (2014 to 2016) measurement 491 data ${ }^{24}$ 

seasonal pattern with that of GWP, but they were quantitatively higher than those of Polyfytos and Ilarion Reservoirs (Table 5). Negative $\mathrm{CO}_{2}$ emissions 495 where observed in Zazari Lake, which are attributed to the increased 496 microbial activity in the hypereutrophic Zazari Lake and the subsequent 497 carbon fixation. Compared to that of oligotrophic-mesotrophic lakes of Ilarion 498 and Polyfytos, Zazari Lake exhibits up to 14 times more Chlorophyll a 499 concentration and significantly worse water quality attributed to domestic 500 pollution from neighboring villages. Thus, seasonal GHGs emissions of a 501 waterbody and especially of a hypertophic one, should be assessed in terms 502 of $\mathrm{CH}_{4}$ emissions or/and GWP in order to count for the impact of microbial 503 activity on GHGs emissions.

504 The statistical correlation between $Y \triangle \Omega P W Q I, F T S I$ and the 505 parameters expressing GHGs emissions i.e., GWP, specific $\mathrm{CO}_{2}$ emissions 506 and specific $\mathrm{CH}_{4}$ emissions, revealed the link between water quality, trophic 507 state and GHGs emissions.

508 In more detail, water quality in terms of $Y \triangle \Omega P W Q I$ presented strong 509 positive correlation (Spearman test, Sig.<0.05) with GWP (Cor. Coef. = 510 0.645, Sig. $=0.022$ ) and specific $\mathrm{CH}_{4}$ emissions (Corr. Coef. $=0.621$, Sig. $=$ 511 0.031). FTSI presents strong positive correlation with GWP (Corr. Coef. = 512 0.813, Sig. $=0.012$ ) and specific $\mathrm{CH}_{4}$ emissions (Corr. coef. $=0.823$, Sig. $=$ 513 0.008). Neither $Y \triangle \Omega P W Q I$ nor FTSI presented statistical correlation with 514 specific $\mathrm{CO}_{2}$ emissions, which as mentioned in previous section is only 515 correlated negatively with turbidity, an indicator of biological growth. The 
516 aforementioned results further support the use of $\mathrm{CH}_{4}$ specific emissions as

517 an indicator for the assessment of GWP that a waterbody exhibits.

518

519

520

521

522

523

524

525

526

527

528

529

530

531

532

533

534

535

536

537

538

539

540

\section{Conclusions}

According to trophic state index, both the six years old Ilarion Reservoir, as well as the forty-three years old Polyfytos Reservoir are classified as oligotrophic through mid-eutrophic reservoirs with "Good" water quality characterization. On the other hand, Zazari Lake, which is considered as a five years old reservoir, is classified as a hypereutrophic Lake with "Poor" water quality characterization.

The application of the water quality index revealed that water quality of Ilarion Reservoir is better than of Polyfytos Reservoir, characterized as "Good", whereas water quality of Polyfytos Reservoir is characterized as "Fair". Zazari Lake exhibited the worst water quality, characterized as "Poor". These results highlight the impact of reservoir's topography and of anthropogenic pressures on trophic state, water quality and the subsequent stabilization time of a reservoir.

The emissions of $\mathrm{CO}_{2}$ and $\mathrm{CH}_{4}$ were relatively low in llarion and Polyfytos Reservoirs. Both reservoirs presented non-significant statistical difference in terms of specific emissions and water quality, despite the fact that Polyfytos Reservoir exhibited three times higher specific $\mathrm{CH}_{4}$ emissions and worst water quality according to the applied indices. On the contrary, Zazari Lake presented significant statistical differences compared to Ilarion and Polyfytos Reservoirs, both in terms of specific emissions and water quality exhibiting one to two orders of magnitude higher $\mathrm{CH}_{4}$ emissions and two to three classes better water quality respectively. 
Water quality and trophic state indices exhibited strong positive

542 correlation with GWP and more specifically with specific $\mathrm{CH}_{4}$ emissions. On

543 the contrary, no statistical correlation between either indices and $\mathrm{CO}_{2}$ specific

544 emissions was found, as a result of carbon fixation. The strong positive

545 correlation between GWP, specific $\mathrm{CH}_{4}$ emissions and temperature justifies

546 the steep increment of GWP in warmer period, with $\mathrm{CH}_{4}$ emissions

547 contributing up to $97 \%$ of the waterbodies' GWP, depending on seasonal

548 water temperature variations.

549 Consequently, $\mathrm{CH}_{4}$ specific emissions, as well as $\mathrm{Y} \triangle \Omega P W Q I$ and $F T S I$

550 can be used as indicators for the assessment of GWP that a waterbody

551 exhibit. Quantifying this relation may result in the creation of a rapid GWP

552 assessment tool for researchers and engineers involved in fresh water and

553 reservoir management.

554 5. Acknowledgements

555 This research was supported by the Natural Environment and Climate

556 Change Agency (NECCA) - Hellenic Ministry of Environment and the Cross-

557 border cooperation program, Interreg IPA 2014-2020. The authors

558 acknowledge Dr. Costa Tsioptsias and Dr. Nikolaos Kaklidis for their

559 assistance regarding samplings and GHGs measurements, as well as

560 Professor Georgios Marnellos from the department of Mechanical Engineering

561 - University of Western Macedonia, Greece for his assistance regarding the

562 accuracy and interpretation of GHGs measurements.

563 6. References

564 1. Dimitriou, K. et al. Greenhouse gases $\left(\mathrm{CO}_{2}\right.$ and $\left.\mathrm{CH}_{4}\right)$ at an 565 urban background site in Athens, Greece: Levels, sources and impact of 
566 atmospheric circulation. Atmospheric Environment. 253, 118372 (2021)

567 https://doi.org/10.1016/j.atmosenv.2021.118372.

568

569

570

571

572

573

574

575

576

577

578

579

580

581

582

583

584

585

586

587

588

589

2. Tremblay, A., Varfalvy, L., Garneau, M. \& Roehm, C. (Eds). Greenhouse gas Emissions-Fluxes and Processes: hydroelectric reservoirs and natural environments. (Springer Science \& Business Media, 2005).

3. Del Sontro, T., Beaulieu, J. J. \& Downing, J. A. Greenhouse gas emissions from lakes and impoundments: Upscaling in the face of global change. Limnology and Oceanography Letters. 3(3), 64-75 (2018) https://doi.org/10.1002/lol2.10073.

4. Beaulieu, J. J., DelSontro, T. \& Downing, J. A. Eutrophication will increase methane emissions from lakes and impoundments during the 21st century. Nature communications. 10(1), $1-5 \quad$ (2019) https://doi.org/10.1038/s41467-019-09100-5.

5. Li, Y., Shang, C., Zhang, W., Niu, L., Wang, L. \& Zhang, H. The role of fresh water eutrophication in greenhouse gas emissions: A review. $\begin{array}{llllll}\text { Science of the Total Environment. } & 768 & 144582 & \text { (2021) }\end{array}$ https://doi.org/10.1016/j.scitotenv.2020.144582

6. Louis, V.L.St., Kelly, C.A., Duchemin, É., Rudd, J.W. \& Rosenberg, D.M. Reservoir Surfaces as Sources of Greenhouse Gases to the Atmosphere: A Global Estimate: Reservoirs are sources of greenhouse gases to the atmosphere, and their surface areas have increased to the point where they should be included in global inventories of anthropogenic emissions of greenhouse gases. BioScience. 50(9), 766-775 (2000) https://doi.org/10.1641/0006-3568(2000)050[0766:RSASOG]2.0.CO;2. 
7. Prairie, Y.T. et al. Greenhouse gas emissions from freshwater

591

592

593

594

595

596

597

598

599

600

601

602

603

604

605

606

607

608

609

610

611

612

613

614

reservoirs: what does the atmosphere see? Ecosystems. 21(5), 1058-1071 (2017) https://doi.org/10.1007/s10021-017-0198-9.

8. Prasad, D. \& Siddaraju, G. Carlson's Trophic State Index for the assessment of trophic status of two Lakes in Mandya district. Adv. Appl. Sci. Res. 3(5), 2992-2996 (2012) https://www.imedpub.com/articles/carlsonstrophic-state-index-for-the-assessment-of-trophic-status-of-twolakes-inmandya-district.pdf.

9. Juutinen, S. et al. Methane dynamics in different boreal lake types. http://urn.fi/URN:NBN:fi-fe2016092624351 (2009).

10. Liikanen, A. et al. Spatial and seasonal variation in greenhouse gas and nutrient dynamics and their interactions in the sediments of a boreal eutrophic lake. Biogeochemistry. 65(1) 83-103 (2003) https://doi.org/10.1023/A:1026070209387.

11. Huttunen, J. T. et al. Fluxes of methane, carbon dioxide and nitrous oxide in boreal lakes and potential anthropogenic effects on the aquatic greenhouse gas emissions. Chemosphere. 52(3), 609-621 (2003) https://doi.org/10.1016/S0045-6535(03)00243-1.

12. European Environment Agency Publications: 3.3. Reservoir and lake eutrophication. https://www.eea.europa.eu/publications/92-9167-0561/page006.html (2016).

13. Paulic, M., Hand, J. \& Lord, L. WATER-QUALITY ASSESSMENT FOR THE STATE OF FLORIDA SECTION 305(B) MAIN REPORT; FLORIDA DEPARTMENT OF ENVIRONMENTAL PROTECTION DECEMBER 1996. 
615

616

617

618

619

620

621

622

623

624

625

626

627

628

629

630

631

632

633

634

635

636

637

638

639

http://www.hillsborough.wateratlas.usf.edu/upload/documents/1996\%20Water

Quality\%20Assessment\%20for\%20the\%20State\%20of\%20Florida\%20Sectio n\%20305(b)\%20Main\%20Report.pdf

14. Duchemin, E., Lucotte, M., Canuel, R. \& Chamberland, A. Production of the greenhouse gases $\mathrm{CH} 4$ and $\mathrm{CO} 2$ by hydroelectric reservoirs of the boreal region. Global Biogeochemical Cycles. 9(4), 529-540 (1995) https://doi.org/10.1029/95GB02202.

15. Sanchez, L. F., Guenet, B., Marinho, C. C., Barros, N. \& de Assis Esteves, F. Global regulation of methane emission from natural lakes. Scientific reports. 9(1), $1-10$ (2019) https://doi.org/10.1038/s41598-01836519-5.

16. Goldenfum, J. A. GHG Measurement Guidelines for Freshwater Reservoirs in: The UNESCO/IHA Greenhouse Gas Emissions from Freshwater Reservoirs Research Project. (International Hydropower Association, IHA, 2010).

17. Zigah, K.P., Kirsten, O., Brand, A., Dinkel, C., Bernhard, W. \& Schubert, C.J. Methane oxidation pathways and associated methanotrophic communities in the water column of a tropical lake. Limnology and Oceanography. 60(2), 553-572 (2015) https://doi.org/10.1002//no.10035.

18. Thottathil, S.D., Reis, P.C.J. \& Prairie, Y.T. Methane oxidation kinetics in northern freshwater lakes. Biogeochemistry 143, 105-116 (2019) https://doi.org/10.1007/s10533-019-00552-x.

19. El-Serehy, H. A., Abdallah, H. S., Al-Misned, F. A., Irshad, R., Al-Farraj, S. A. \& Almalki, E. S. Aquatic ecosystem health and trophic status classification of the Bitter Lakes along the main connecting link between the 
640 Red Sea and the Mediterranean. Saudi journal of biological sciences. 25(2), 641 204-212 (2018) https://doi.org/10.1016/j.sjbs.2017.12.004. Water Quality Indices 9-24 (Elsevier, 2012).

21. Zotou, I., Tsihrintzis, V. A. \& Gikas, G. D. Performance of Seven

Water Quality Indices (WQIs) in a Mediterranean River. Monitoring and Assessment. 191(8), 505 (2019) https://doi.org/10.1007/s10661-019-7652-4.

Amanatidou, E. 2017. Evaluation of water quality indices adequacy in characterizing the physico-chemical water quality of lakes. Environmental Processes. 4(1), 35-46 (2017). https://doi.org/10.1007/s40710-017-0218-y

23. Noori, R., Berndtsson, R., Hosseinzadeh, M., Adamowski, J. F. Sanitation Foundation Water Quality Index. Environmental Pollution. 244, 575-587 (2019). http://dx.doi.org/10.1016/j.envpol.2018.10.076.

24. Samiotis, G., Pekridis, G., Kaklidis, N., Trikoilidou, E., 656 Taousanidis, N. \& Amanatidou, E. Greenhouse gas emissions from two 657 hydroelectric reservoirs in Mediterranean region. Environmental Monitoring 658 and Assessment. 190(6), 363. (2018b) https://doi.org/10.1007/s10661-018$659 \quad \underline{6721-4}$.

25. Samiotis, G., Trikoilidou, E., Tsikritzis, L. \& Amanatidou, E. 661 Comparative water quality assessment between a young and a stabilized 662 hydroelectric reservoir in Aliakmon River, Greece. Monitoring and Assessment. 190(4), 234 (2018a) https://doi.org/10.1007/s10661-018-6602-x. 
Works Association, Water Pollution Control Federation, \& Water Environment

666

667

668

669

670

671

672

673

674

675

676

677

678

679

680

681

682

683

684

685

686

687

688

Federation, Standard methods for the examination of water and wastewater (American Public Health Association, 2017)

27. ISO-International Organization for Standardization. Water quality-determination of dissolved $\mathrm{Li}+. \mathrm{Na}+, \mathrm{NH} 4+, \mathrm{K}+, \mathrm{Mn} 2+, \mathrm{Ca} 2+, \mathrm{Mg} 2+$, Sr2+ and $\mathrm{Ba} 2+$ using ion chromatography-Method for water and waste water ISO 14911:1998.

28. ISO-International Organization for Standardization. Determination of dissolved anions by liquid chromatography of ions-Part 1: Determination of bromide, chloride, fluoride, nitrate, nitrite, phosphate and sulphate. ISO 10304-1: 2007.

29. Brooker, M.R., Bohrer, G. \& Mouser, P.J. Variations in potential $\mathrm{CH} 4$ flux and $\mathrm{CO} 2$ respiration from freshwater wetland sediments that differ by microsite location, depth and temperature. Ecological Engineering. 72, 84$94(2014)$

30. Mavromatidou C. et al. 2020. A water quality assessment tool for decision making, based on widely used water quality indices. 4th EWaS Conference, Corfu, in press (2020). http://dx.doi.org/10.1016/j.ecoleng.2014.05.028

31. Gikas, G.D., Sylaios, G.K., Tsihrintzis, V.A., Konstantinou, I.K., Albanis, T. \& Boskidis, I. Comparative evaluation of river chemical status based on WFD methodology and CCME water quality index. Science of the Total Environment.

745 , 140849 (2020) https://doi.org/10.1016/j.scitotenv.2020.140849. 
32. Ministry of Rural Development and Food of Greece (a).

690 Monitoring of Chemical Quality of Water (Surface and Groundwater) for

691 Irrigation on a River Basin Scale for the Rivers of Macedonia, Thrace and 692 Thessaly, Greece: Results for Aliakmon River Basin (in Greek), 693 http://www.minagric.gr/ardeftika/files/results/geol/15.RESULTS ALIAKMONA. 694 pdf (2020)

695 33. Ministry of Rural Development and Food of Greece (b). 696 Monitoring of Chemical Quality of Water (Surface and Groundwater) for 697 Irrigation on a River Basin Scale for the Rivers of Macedonia, Thrace and 698 Thessaly, Greece: Results for Vegoritida's catchment area (in Greek). 699 http://www.minagric.gr/ardeftika/files/results/hydro/10.\%20HYDRO_VEGORIT $700 \quad$ IDAS.pdf (2020)

701 34. Huber, W. C. et al. A classification of Florida lakes. Water 702 Resources Research Center Publication, 72 (1982) 703 https://ufdc.ufl.edu/UF00000142/00001.

35. Carlson, R. E. A trophic state index for lakes 1. Limnology and 705 oceanography. 22(2), $361-369$

706 https://doi.org/10.4319/lo.1977.22.2.0361.

36. Richardson, J. Water Quality Report for Selected Lakes and Streams. Leon County Public Works. Division of Engineering Services. Florida's Capital County, United States. p. 23. http://cms.leoncountyfl.gov/Portals/0/publicworks/engservices/docs/WQR Ma y2013 comp.pdf (2013).

37. EPA, 2021, Understanding Global Warming Potential. www.epa.gov. (2021) 
38. Walker, W.W. Empirical Methods for Predicting Eutrophication in

715 Impoundments, Rep. 3, Phase II. Model Refinements. Tech. Rep. E-81-9.

716 U.S. Army Engineer Waterways Experiment Station, Vicksburg, MS.

717 https://www.semanticscholar.org/paper/Empirical-Methods-for-Predicting-

718 Eutrophication-in-Walker/c04aaf1218df008dac5e7067bd9e680ef7163977

719 (1985).

720

39. Yu, H., Tsuno, H., Hidaka, T. \& Jiao, C. Chemical and thermal

stratification in lakes. Limnology. 11, 251-257

(2010)

722 https://doi.org/10.1007/s10201-010-0310-8.

723 40. Leach, T.H. et al. Patterns and drivers of deep chlorophyll maxima structure in 100 lakes: the relative importance of light and thermal 725 stratification. Limnol. Oceanogr. 63(2), 628-646 https://doi.org/10.1002/Ino.10656.

41. Søballe, D.M., Kimmel, B.L., Kennedy, R.H. \& Gaugush, R.F. Biodiversity of the Southeastern United States: Aquatic Communities. (JohnWiley \& Sons Inc., 1992).

42. Cotterill, N. G. \& Thornton, J. A. Hydroclimate development 731 following impoundment in a tropical African manmade lake (Lake Robertson, 732 Zimbabwe). Journal of the Limnological Society of Southern Africa, 11, 54-61 733 (1985) https://doi.org/10.1080/03779688.1985.9632829.

43. Samiotis, G., Trikoilidou, E., Michailidis, A., Zagana, E. \& 735 Amanatidou, E. Comparative water quality assessment of a new and an old 736 reservoir in Aliakmon River using both statistical tools and a modified NSF 737 water quality index. 13th International Conference on Protection and 738 Restoration of the Environment. (2016). 
https://www.semanticscholar.org/paper/Comparative-water-quality-

740 assessment-of-a-new-and-a-Samiotis-

741 Trikoilidou/9ee15da0e417ace6085b6a87d4fe78382ffd47a6.

742 44. Giles, J. Methane quashes green credentials of hydropower. $743 \quad$ Nature. 444(30), 524-525 (2006).

744 45. Davidson, T.A. et al. Eutrophication effects on greenhouse gas 745 fluxes from shallow lake mesocosms override those of climate warming. 746 Global Change Biology. 21(12), 4449-4463 (2015) doi: 10.1111/gcb.13062.

747 46. Alfreider, A., Baumer, A., Bogensperger, T., Posch, T., Salcher, 748 M.M. \& Summerer, M. $\mathrm{CO}_{2}$ assimilation strategies in stratified lakes: Diversity 749 and distribution patterns of chemolithoautotrophs. Environ. Microbiol. 19(7), 750 2754-2768 (2017) https: doi:10.1111/1462-2920.13786.

751 47. Cole, J. J. \& Prairie, Y. T. Dissolved CO2 in Encyclopedia of 752 Inland Waters. 2, 30-34 (Elsevier, 2009). https://doi.org/10.1016/B978753 012370626-3.00091-0. 


\section{Supplementary Files}

This is a list of supplementary files associated with this preprint. Click to download.

- Graphicalabstract.docx 